\title{
Who Suffers the Most from Abusive Supervision? A Moderated Mediation Model
}

\author{
Yeon Sun Gwak $\quad$ Yeseul Jung $\quad$ Young Woo Sohn ${ }^{\dagger}$ \\ Department of Psychology, Yonsei University
}

\begin{abstract}
We examined the interactive effects of calling and competitive climate on the relationship between abusive supervision and turnover intention via organizational cynicism. We hypothesized that high levels of calling would strengthen, and high levels of competitive climate would mitigate, the negative indirect effects of abusive supervision on turnover intention via organizational cynicism. We conducted a survey using a sample of U.S. employees ( $N=236)$ to test five hypotheses. As predicted, results demonstrate that under a high level of abusive supervision, individuals were more likely to become cynical about the organization, which in turn heightened turnover intention. Moderated mediation analyses found that calling exacerbated, but competitive climate attenuated, the mediating effect of organizational cynicism on the relationship betwen abusive supervision and turnover intention. Underlying mechanisms and implications, as well as avenues for future research, are discussed.
\end{abstract}

Key words: A busive Supervision, Calling, Competitive Climate, Organizational Cyniesm, Turnover Intention

† 교신저자 : 손영우, 연세대학교 심리학과, ysohn@yonse..xc.kr 
Abusive supervision has been identified as a destructive leadership method that impairs job effectiveness (Duffy, Ganster, \& Pagon, 2002; Tepper, 2000). Despite its derrimental effects, abusive supervision is evident in many organizations. Based on a recent study, between $10 \%$ and $16 \%$ of employees in the U.S. experience abusive supervision on a daily basis (Namie \& Namie, 2000). An abundant literature has documented the negative effects of abusive supervision; however, most of these studies have focused on the simple negative impacts of abusive supervision. Only few researchers have examined potential moderators and mediators of the relationship between abusive supervision and job outcomes. Some of the studies take situational moderators into consideration, such as mechanistic versus organic structures (Arye, Sun, Chen, \& Debrah, 2008) and hostile work climates (Mawritz, Mayer, Hoobler, Wayne, \& Marinova, 2012). It still needs more investigation of situational and individual moderators in order to further develop the extant literature. Thus, we set out to examine not only why abusive supervision increases turnover intention, but also who suffers the most from this type of supervision.

Both organizational cynicism and turnover intentions are two attitudinal variables which are considered to be a major consequences of abusive supervision. Those attitudes could result in deleterious results and significant amount of budget loss in organization (Mitchell, Holtom,
\& Le, 2001). Hinkin and Tracey (2000) mentioned that the cost of turnover was estimated as much as 5 percept of operational budget in organization including replacement and separation cost. Given that the significant effect of turnover on organizations, we tried to investigate the mechanism so that we could understand how abusive supervision leads to turnover intention. There was relatively short of literature with regard to employees' affective reactions as mediators between abusive supervision and turnover intention. Thus, we hypothesized organizational cynicism would mediate the relationship between abusive supervision and turnover intention.

According to Tepper (2007), the influence of abusive supervision is not homogeneous for all employees. In this review, Tepper introduced an emergent model of abusive supervision which integrates four categories of moderating variables: (a) dispositional characteristics of employees, (b) employees' upward communication behavior, (c) characteristics and behaviors of the supervisor, and (d) characteristics of employees' work context. In line with this proposed model of abusive supervision, our research is based on the assumption that the impact of abusive supervision can be significantly differed by the employe's dispositional characteristics and employee's work context.

In terms of individual characteristic, we particularly focused on individuals' vocational calling. There is emerging but narrow empirical 
research with regard to vocational calling. Vocational calling is relatively a new concept in this field, so it needs to be elucidated how it works under injustice organizational conditions such as abusive supervision. Vocational calling has been known to be related with a wide variety of positive job outcomes, and negatively related with turnover intentions. Spreitzer (1995) proposed that abusive supervision and job outcome relationship can be moderated by how much employees value the work they do. We predicted that calling would moderate the negative impact of abusive supervision. Therefore, it needs more examination how individuals' vocational calling affects their job attitudes when they are under the abusive supervision.

With regard to work context, we chose competitive organizational climate to see how organizational climate plays a role in the relationship between abusive supervision and job attitudes. Tepper (2007) suggested that organizational context can serve as the moderator on the relationship between abusive supervision and negative job outcomes. According to previous study (Arnold, Flaherty, Voss \& Mowen, 2009), the competitive dimate could mitigate the aversive effects of the work stressors. We predicted that competitive organizational climate would moderate the relationship between abusive supervision and its negative impact. Thus, we investigated the interactive effects of the moderators of abusive supervision and considered both calling as an individual factor and competitive dimate as an organizational factor.

\section{Theory and Hypothesis Development}

\section{Abusive Supervision}

Tepper (2000) defines abusive supervision as "the sustained display of hostile verbal and nonverbal behaviors, excluding physical contact" (p. 178). Abusive supervision is not simply the subordinate's interpretation, but also prolonged and sustained mistreatment of the subordinate, which incurs serious negative consequences for organizations. Some might argue that abusive supervision is just one kind of workplace bullying. Admittedly, mistreatment at workplace can be committed by a variety sources, including coworkers, outsiders of organizations like clients or customers (Hershcovis \& Barling, 2010). However, the effects of abusive supervision are more influential compared with other forms of maltreatments.

In line with significant impacts of abusive supervision, the extant literature has examined negative influences of abusive supervision in many aspects in the organizations. With regard to psychological consequences, it has been found that abusive supervision is associated with higher psychological distress (Richman, Flaherty, Rospenda, \& Christensen, 1992), job dissatisfaction, lower self-efficacy (D uffy et al., 2002), less organizational commitment, 
hel plessness (A shforth, 1994), higher counterproductive work behavior ( $\mathrm{H}$ an \& Park, 2009) and higher organizational cynicism. In terms of job effectiveness, under abusive supervision, employees showed more counterproductive work behaviors, less citizenship behavior, poor performance, injustice perception toward organization, and higher turnover intentions (Aryee et al., 2008; Harris, Kacmar, \& Zivnuska, 2007; Jun \& Jeung, 2015; Kuo, Chang, Quinton, Lu, \& Le, 2015; Liu, \& Wang, 2013; Martinko, Harvey, Brees, \& Mackey, 2013; Park, Son, \& Yun, 2014; Tepper, 2000).

The Mediating Role of Organizational Cynicism

Organizational cynicism, by definition, is a negative attitude about an organization (Dean, Brandes, \& Dharwadkar, 1999) in which employees believe that their organization lacks integrity. In turn, this triggers negative affect with respect to the organization and behaviors that express criticism toward it. If employees have a certain level of expectations for the organization and their supervisors, but these expectations are not satisfied, they are more likely to feel negative about the organization and display withdrawal behavior ( $\mathrm{Hom}, \mathrm{Griffeth}$, \& Sellaro, 1984). In their meta-analysis of the literature on cynicism, Chiaburu, Peng, Oh, Banks, and Lomeli (2013) found that cynicism is associated with job dissatisfaction and higher turnover intention. They argue that when employees evaluate their working conditions negatively, this triggers dissatisfaction among employees and increases turnover intention. Also, Bedeian (2007) found that organizational cynicism ultimately leads to turnover intention.

Tepper (2000) suggests that an abusive supervisor may motivate strong negative evaluations of the job in general and cause the employee to have a negative attitude toward both the supervisor and the organization. Abusive supervision engenders negative affective states among employees (Atwater, Kim, W itt, Latheef, Callison, Elkins, \& Zheng, 2015; Harvey, Stoner, \& Kacmar, 2007), and feeling victimized enhances negative affect, which in turn leads to maladaptive coping by employees (Glasø, Homdal, \& Einarsen, 2011). Abusive supervision not only affects employees' negative affective states toward their supervisor, but also this negative attitude can be extended toward their organization overall. On the basis of Levinson's (1965) agent theory, supervisors and other authorities in organizations are viewed as representatives of the larger organization and are perceived to represent the organization's interests (Eisenberger, Stinglhamber, Vandenberghe, Sucharski, \& Rhoades, 2002; Levinson, 1965). Therefore, the negative impact of abusive supervision can be generalized by employees to represent the negative characteristics of the organization. As a result, abusive supervision can 
cause an increase in organizational cynicism and withdrawal, leading to turnover intention or actual turnover. Taken together, we hypothesized that organizational cynicism would mediate the relationship between abusive supervision and turnover intention.

Hypothesis 1: Organizational cynicism will mediate the relationship between abusive supervision and turnover intention.

\section{The Moderating Process}

Previous studies have mainly focused on the direct negative impact of abusive supervision on job outcomes. Our model, in contrast, highlights the moderating role of individual and organizational factors to explain the relationship between abusive supervision and turnover intention via organizational cynicism; we aimed to examine the individual characteristics and organizational contexts that moderate the mediating effects of organizational cynicism between abusive supervision and turnover intention. Accordingly, we primarily focused on the moderating effects of the employee's occupational calling and the organization's competitive dimate.

\section{The Moderating Role of Calling}

The concept of calling arose from a religious context, but researchers now use the term to describe the inner experience of a resolve to work and a sense of purpose at work ( $\mathrm{H}$ all \& Chandler, 2005). Abundant research has examined the positive impact of occupational calling on life, job-, and health-related outcomes, and it has been found to have a positive relationship with life and job satiffaction (Creed, Rogers, Praskova, \& Searle, 2014; Duffy, Bott, Allan, Torrey, \& Dik, 2012; Praskova, Creed \& Hood, 2015). Individuals with high calling report finding greater meaning in life and work (Bunderson \& Thompson, 2009) than those with low calling.

Although the positive aspects of calling have received widespread attention, few studies have considered the dark side of calling (Bunderson \& Thompson, 2009; Duffy, Douglass, \& Autin, 2015; Gazica \& Spector, 2015). Recently, some researchers suggested that there may be negative effects when one's calling could not be lived out. Gazica and Spector (2015) found that individuals with calling experience positive outcomes only when their calling is satisfied. If it is not, having a calling might have a deleterious effect on outcomes compared to not having a calling. When individuals with calling could not pursue via their work, they may suffer from stress, depression and frustration (Berkelaar \& Buzzanell, 2015).

Duffy et al. (2012) have demonstrated that merely having a calling does not explain greater career commitment; only when individuals live their calling will they be more committed to 
their careers. If living one's calling is an important moderator that enables the calling to produce positive results, what happens when individuals with high calling are unable to achieve it? Individuals who have a calling but are not living it showed higher withdrawal intention at work (Berg, Grant, \& Johnson, 2010). Further, it was found that not living one's calling is related to low levels of physical and psychological well-being, job satisfaction, and high levels of intention to withdraw. These individuals may be seeking a more supportive environment that is congruent with their personal values and provides the opportunity to live their calling.

The literature on psychological contract breach (Andersson, 1996) assumes that employees share a belief that the organization is obligated to fulfill its part of a reciprocal exchange between employee and organization. When employees feel that the organization is not fulfilling its reciprocal obligations-and thereby violating the psychological contract-employees are likely to fed resentment (Andersson, 1996). Individuals with high calling have high moral criteria for management and employers (Bunderson \& Thompson, 2009), such that they judge management decisions against a high moral standard when such decisions are related to the individual's calling. When they are confronted with abusive supervision, it is more likely that they will perceive a greater degree of unmet expectations for moral obligations, which would represent a greater psychological contract breach. In addition, incongruence between personal expectations for a promised outcome and organizational expectations (e.g., as evidenced by abusive supervision) might also seriously violate a psychological contract for individuals with high calling. Due to abusive supervision, those with calling will perceive a lack of congruence between their values and those of the organization and, they will show stronger indirect effect of abusive supervision on turnover intention via organizational cynicism. Therefore, we hypothesized that those with low calling would suffer less from abusive supervision than those with high calling, leading to mitigate the indirect effect of abusive supervision on turnover intention via organizational cynicism.

Hypothesis 2: Calling moderates the indirect effect of abusive supervision on turnover intention via organizational cynicism such that the indirect effect will be stronger among individuals high in calling than individuals low in calling.

The Moderating Role of Competitive Organizational Climate

Many U.S. organizations' work environments have become increasingly competitive. Despite of the prevalence of competitive climate, only limited amount of research has been conducted. Keeping abreast of this increasingly competitive 
climate requires further research on the moderating effects of a competitive climate on the indirect effect of abusive supervision on turnover intention via organizational cynicism.

Brown, Cron, and Slocum (1998, p 89) defined competitive climate as a psychological work environment where "employees perceived organizational rewards to be contingent on comparisons of their performance against that of their peers." In a competitive climate, employees are motivated only by attaining rewards as a results of competition between coworkers (Brown, Cron, \& Slocum, 1998), not by being supported by coworkers or supervisors. Jones, Davis, and Thomas (2015) suggest that in a competitive dimate, interactions with coworkers might not be supportive or rewarding; employees could be pressured to outperform coworkers, and mainly focus on improving their own performance rather than maintaining supportive relationships with other members of the organization.

Arnold, Flaherty, Voss, and Mowen (2009) argue that a competitive climate is more likely to weaken the adverse effects of stressors at work. Challenge stressors, such as an organization's competitive climate, are rather positively related with motivation, and employees are able to deal with the stressor (LePine, Podsakoff, \& LePine, 2005). Bakker, Demerouti, and Verbeke (2004) also demonstrate that employees are able to deal with stressors in a competitive climate; due to greater emphasis on job performance, employees are motivated to keep job stressors from negatively influencing their job performance (Arnold et al., 2009).

Such employees are less likely to interpret abusive supervisory behavior as a destructive behavior for their performance, and might think that abusive supervision could be less unjustifiable under high pressure to excel. Thus, in the context of a competitive climate, they may be less likely to attribute their supervisor's abusive behavior to destructive and injuryinitiation motives. Indeed, Liu, Liao, and Loi (2012) found that a negative relationship between abusive supervision and team creativity was mitigated when subordinates attributed their abusive supervisory behaviors as performancepromotion motives rather than injury-initiation motives.

On the basis of the literature, we hypothesized that a competitive organizational climate would weaken the relationship between abusive supervision and turnover intention via organizational cynicism. In a high competitive climate, employees would interpret abusive supervision less negatively, and therefore showing lower organizational cynicism and turnover intention; in turn, they are not as affected by an abusive supervisor's behavior.

Hypothesis 3: Competitive climate moderates the indirect effects of abusive supervision on turnover intention via organizational cynicism such that the indirect effect will be stronger in a low competitive organizational dimate than in 


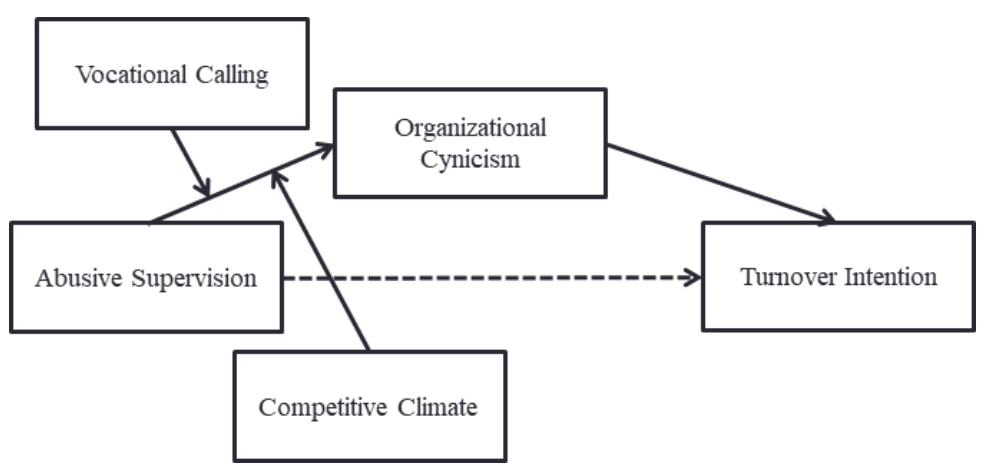

Figure 1. A model of the relationship between abusive supervision and turnover intention

a high competitive organizational climate

The purpose of this study, therefore, is to theorize regarding and empirically integrate such moderating effects to better understand the relationship between abusive supervision and turnover intention via organizational cynicism. Our overall model is shown in Figure 1.

\section{Method}

\section{Participants and Procedure}

We conducted a study of 236 employees in the U.S. using Amazon.com's Mechanical Turk (MTurk). Participants qualified for inclusion if they were currently employed and had a workplace supervisor who also resided in the U.S., and received $\$ 0.45$ in compensation. The sample consisted of 132 women and 104 men $($ Mage $=34.63$, SDage $=10.67)$. Average organizational tenure was approximately 6 years
$(M=5.59, S D=4.95)$. Cronbach's alphas for all variables are presented in Table 1.

Measures

\section{Abusive supervision}

We measured abusive supervision using Tepper's (2000) 15-item scale on a 5-point Likert scale that ranged from 1 (I can't remember him/her ever using this behavior with me) to 5 (He/she uses this behavior very often with me). Participants were asked to rate the frequency of the supervisor's abusive behaviors. The sample items from the scale are "My supervisor reminds me of my past mistakes and failures" and "My boss is rude to me". Coefficient alpha for the scale was .96 .

\section{Vocational calling}

We assessed participants' calling using Hagmaier and Abele's (2012) 9-item Multidimensional Calling Scale on a 6-point Likert scale that ranged from 1 (strongly 
disagree) to 6 (strongly agree). The scale has three subscales: Identification and PersonEnvironment Fit, Transcendent Guiding Force, and Sense \& Meaning and ValueDriven Behavior. The sample items from the scale are "I am destined to do exactly the job I do" and "I follow an inner call that guides me on my career path". Coefficient alpha for the scale was .93 .

\section{Competitive climate}

We employed Brown, Cron, and Slocum's (1998) 4-item competitive dimate scale using a 7-point Likert scale that ranged from 1 (strongly disagre) to 7 (strongly agre). The sample items from the scale are, "My manager frequently compares my performance with that of my coworkers" and "Everybody is concerned with being the top performer". Coefficient alpha for the scale was .84 .

\section{Organizational cynicism}

We assessed organizational cynicism using Dean, Brandes, and Dharwadkar's (1998) 13item scale using a 5-point Likert scale that ranged from 1 (never) to 5 (always). The sample items from the scale are, "When I think about my organization, I experience irritation" and "I criticize my organization's practices and policies with others". Coefficient alpha for the scale was .95 .

\section{Turnover intention}

We adapted Becker's (1992) 4-item intention- to-quit scale using a 7-point Likert scale that ranged from 1 (strongly disagree) to 7 (strongly agree). The first two items came from the Michigan Organizational Assessment Questionnaire (Cammann, Fichman, Jenkins, \& Klesh, 1979), and the other two items from the Organizational Commitment Questionnaire (OCQ). The sample items are, "I often think about quitting" and "There's not too much to be gained by sticking with the organization indefinitely". Coefficient alpha for the scale was .90 .

\section{Control variables}

On the basis of a review of the literature, we identified three variables that could confound with our main variables: gender, age, and negative affectivity. We controlled for age because it is perceived to be less costly for younger employees to leave a job and seek alternatives than for older ones (Barnes $\&$ Jones, 1974), and an employee's age is significantly negatively related to abusive supervision (Zhang \& Bednall, 2015). We also controlled for gender, based on Cotton and Tuttle (1986), which found there is a significant corelation of gender to turnover. Finally, Cropanzano, James, and Konovsky (1993) found that negative affectivity has a considerable positive impact on the turnover intention, hence we controlled for negative affectivity. 


\section{Analysis}

Before testing the hypotheses, we conducted preliminary analysis using inter-correlational analysis. Due to the signifiant effects on turnover intention, thre control variables (age, gender, and negative affectivity) were controlled in all analyses. To test the hypotheses in this study, we employed SPSS 18.0 and Mplus. For $H$ ypothesis 1 , we tested the mediation effect of organizational cynicism on the relationship between abusive supervision and turnover intention using PROCESS macro mode 4 (Preacher \& Hayes, 2007). For Hypotheses 2 and 3 , to prevent multicollinearity, variables were mean-centered, and the interaction terms were calculated from centered variables. Then we conducted the moderated mediation effect employing PROCESS macro models 2 and 9 (Preacher \& Hayes, 2007). We further tested the significance of difference in indirect effects using Mplus.

\section{Results}

\section{Preliminary Analyses}

Descriptive statistics and bivariate correlations among study variables are shown in Table 1. Abusive supervision was positively associated with turnover intention $(r=.34, p<.001)$ and cynicism ( $r=.60, p<.001)$. As hypothesized,

Table 1. Descriptive Statistics and Bivariate Correlations

\begin{tabular}{|c|c|c|c|c|c|c|c|c|c|c|c|}
\hline & M & SD & 1 & 2 & 3 & 4 & 5 & 6 & 7 & 8 & 9 \\
\hline 1. Tenure & 5.59 & 4.95 & - & & & & & & & & \\
\hline 2. Gender & 1.56 & .50 & -.03 & - & & & & & & & \\
\hline 3. Age & 34.63 & 10.67 & $.38 * *$ & -.03 & - & & & & & & \\
\hline $\begin{array}{l}\text { 4. Negative } \\
\text { Affectivity }\end{array}$ & 1.65 & .82 & -.09 & $-.13^{*}$ & $-.13^{*}$ & $(.95)$ & & & & & \\
\hline $\begin{array}{l}\text { 5. Abusive } \\
\text { Supervision }\end{array}$ & 1.59 & .81 & .08 & $-.13^{*}$ & -.08 & $.49 * *$ & $(.96)$ & & & & \\
\hline $\begin{array}{l}\text { 6. Competitive } \\
\text { Climate }\end{array}$ & 3.73 & 1.43 & .03 & $-.20 * *$ & -.01 & .11 & $.27 * *$ & (.84) & & & \\
\hline 7. Cynicism & 2.34 & 1.01 & .11 & -.07 & .00 & $.46 * *$ & $.60 * *$ & $.18^{* *}$ & $(.95)$ & & \\
\hline 8. Calling & 4.05 & 1.20 & .19 & .10 & -.03 & $-.21 * *$ & -.09 & .05 & $-.15^{*}$ & $(.93)$ & \\
\hline 9. Turnover & 3.63 & 1.77 & -.07 & -.05 & $-.18^{*}$ & $.39 * *$ & $.34 * *$ & .12 & $.49 * *$ & $-.44^{* *}$ & (.90) \\
\hline
\end{tabular}

$\mathrm{N}$ ote $\mathrm{N}=236$. a coefficients are provided in parentheses. male $=1$; female $=2$.

$* p<.05 . * * p<.01$. 
cynicism was strongly related to turnover intention $(r=.49, p<.001)$.

The Mediating Effect of Cynicism

Hypothesis 1 predicted that cynicism would mediate the relationship betwen abusive supervision and turnover intention. Regression results for testing mediation are shown in Table 2. After controlling for age, gender, and negative affectivity, abusive supervision was positively related with organizational cynicism (B $=.63, p<.001) . \mathrm{N}$ ext, abusive supervision and turnover intention were significantly positively related $(B=.42, p<.01)$, and cynicism and turnover intention were significantly related $(B=.72, p<.001)$. Therefore, Hypothesis 1 was fully supported. Lastly, the relationship between abusive supervision and turnover intention was considerably weakened when cynicism-the mediating variable-was added to the analysis $(B=-.04, p>.05)$. In addition, the significant relationship between abusive supervision and turnover intention became non significant, which suggests a full mediating effect model: That is, cynicism plays a full mediating role in the relationship betwen abusive supervision and turnover intention.

To further estimate the significance of this mediating effect, we employed a bootstrapping method. Using an SPSS macro, we resampled 5,000 times, and obtained estimates and 95\% confidence intervals. The bootstrap coefficient was .45 , and the confidence interval did not include $0,95 \% \mathrm{Cl}=[.29, .65]$, which confirms that the mediating effect of cynicism was significant (Preacher, Rucker, \& Hayes, 2007). Sobel test results also showed that the indirect effect

Table 2. Regression Results for Testing Mediation

\begin{tabular}{cccc}
\hline \multirow{2}{*}{ Factor and Statistic } & Cynicism & \multicolumn{2}{c}{ Turnover Intention } \\
\cline { 3 - 4 } Constant & .54 & $2.63^{* * *}$ & Step2 \\
Gender & .06 & .04 & $2.24^{* * *}$ \\
Age & .01 & $-.02^{*}$ & -.01 \\
Negative Affectivity & $.28^{* *}$ & $.61^{* * *}$ & $-.03^{* *}$ \\
Abusive Supervision & $.61^{* * *}$ & $.42^{* *}$ & $.40^{* *}$ \\
Organizational Cynicism & & & -.04 \\
$\mathrm{~F}$ & $39.58^{* * *}$ & $13.87^{* * *}$ & $.72^{* * *}$ \\
$\mathrm{R}^{2}$ & $.41^{* * *}$ & $.19^{* * *}$ & $19.15^{* * *}$ \\
Adjusted $\mathrm{R}^{2}$ & .40 & .18 & $.29 * * *$ \\
\hline
\end{tabular}

N de $* p<.05,{ }^{* *} p<.01, * * * p<.001$. 
was significant (Sobel $Z=4.75, p<.001$ ). Therefore, Hypothesis 1 was supported.

The Moderated Mediating Effect of Calling and Competitive Climate

We analyzed moderated mediation (Muller, Judd, \& Y zerbyt, 2005) to test Hypotheses 2 and 3 using PROCESS macro models 2 and 9. Following Preacher et al.'s (2007) recommendation, we examined four conditions: (a) the significant effects of abusive supervision on turnover intention, (b) the significant interactions between abusive supervision and the two moderators, (c) the significant effect of organizational cynicism on turnover intention, and (d) differences in the conditional indirect effects of abusive supervision on turnover intention via organizational cynicism, across low and high levels of each of the moderators. Moderated mediation would be supported if the strength of the mediating effect via organizational cynicism differs depending on level of calling and competitive climate.

First, Hypothesis 1 supported condition (a), such that abusive supervision had a significant positive effect on turnover intention $(B=.42, p$ $<.01$ ). Next, condition (b) was also supported (see Table 3); we demonstrated that interactions for abusive supervision with both calling ( $B=$ .14, $\mathrm{t}=2.47, p<.05)$ and competitive climate $(B=-.13, t=-2.31, p<.05)$ were significant for predicting organizational cynicism.
To further understand the moderating effect, we plotted the interaction graph using one standard deviation above and below the mean of calling, and competitive climate (see Figure 2). Condition (c) was supported by results for Hypothesis 1, which showed a significant effect of organizational cynicism on turnover intention ( $B$ $=.72, p<.001$ ). Finally, condition (d) was also confirmed by examining differential strengths of the conditional indirect effects of organizational cynicism by levels of two moderators.

To test condition (d), we operationalized high and low levels of calling and competitive climate as one standard deviation above and below the mean scores for the respective moderators. First, we tested the conditional indirect effects on abusive supervision by level of calling. Those with high calling showed a stronger conditional indirect effect of organizational cynicism (Conditional indirect effect $=.62$, SE $=.14$, $95 \% \mathrm{Cl}=[.37, .92])$, than those with low calling (Conditional indirect effect $=.38, \mathrm{SE}=$ $.11,95 \%$ C I $=[.20, .64])$. We used MPlus to test the significance of difference between conditional indirect effects, and conditional indirect effects at high and low calling were significantly different from each other ( $\Delta$ indirect effect $=-.24,95 \%$, SE $=.13, \mathrm{Cl}=[-.55$, -.03]). Therefore, Hypothesis 2 was supported.

Second, we tested the conditional indirect effects of abusive supervision by level of competitive dimate. Organizational cynicism 
Table 3. Regression Results for Conditional Indirect Effects

\begin{tabular}{ccccccccc}
\hline \multirow{2}{*}{ Variable } & \multicolumn{3}{c}{ Organizational Cynicism } & \multicolumn{5}{c}{ Turnover Intention } \\
\cline { 2 - 9 } & $\mathrm{B}$ & SE & $\mathrm{t}$ & $\mathrm{p}$ & $\mathrm{B}$ & $\mathrm{SE}$ & $\mathrm{t}$ & $\mathrm{p}$ \\
\hline Constant & .63 & .63 & 1.00 & .320 & 2.23 & .56 & 3.95 & .000 \\
Gender & .09 & .10 & .81 & .418 & -.01 & .20 & -.03 & .973 \\
Age & .01 & .01 & .99 & .322 & -.03 & .01 & -2.77 & .006 \\
NA & .29 & .07 & 4.00 & .000 & .40 & .14 & 2.83 & .005 \\
AS & .66 & .34 & 1.94 & .054 & -.04 & .16 & -.23 & .820 \\
Calling & -.25 & .10 & -2.61 & .001 & & & & \\
ComC & .21 & .09 & 2.44 & .015 & & & & \\
AS x Calling & .14 & .06 & 2.47 & .014 & & & & \\
AS x ComC & -.13 & .06 & -2.31 & .022 & & & & \\
Organizational Cynicism & & & & & .72 & .13 & 5.72 & .000 \\
\hline
\end{tabular}

$\mathrm{N}$ ate $\mathrm{NA}=$ Negative Affectivity, $\mathrm{AS}=$ Abusive Supervision, $\mathrm{ComC}=$ Competitive Climate
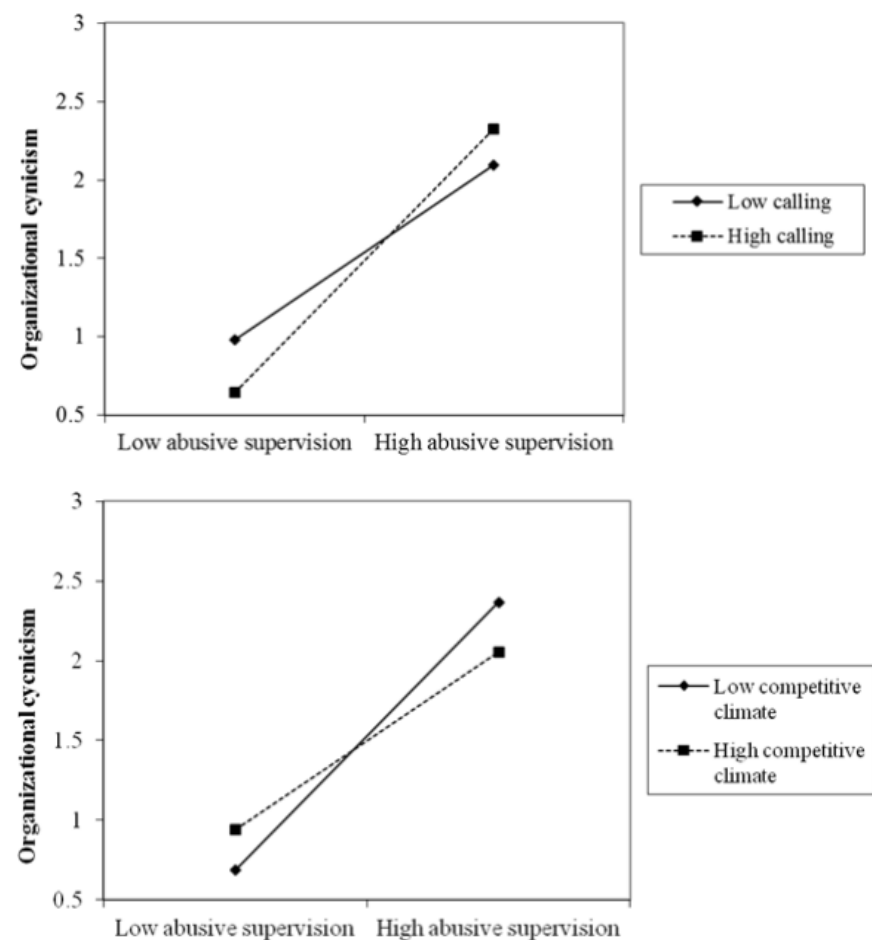

Figure 2. Moderating effect of calling and competitive climate on the relationship between abusive supervision and organizational cynicism 
mediated the relationship betwen abusive supervision and turnover intention more strongly in a low competitive climate (Conditional indirect effect $=.65, \mathrm{SE}=.17,95 \% \mathrm{Cl}=$ $[.37,1.02])$ than in a high competitive climate (Conditional indirect effect $=.35, \mathrm{SE}=.09$, $95 \% \mathrm{Cl}=[.20, .56])$. We used Mplus to test the significance of difference of conditional indirect effects, and conditional indirect effects at high and low competitive climate were significantly different from each other $(\Delta$ indirect effect $=.29, \mathrm{SE}=.16,95 \%, \mathrm{Cl}=[.03$, .67]). Accordingly, Hypothesis 3 was also supported.

\section{General Discussion}

Despite a burgeoning literature on the negative effects of abusive supervision, few empirical studies have been conducted to identify when and why abusive supervision exerts more serious effects. Our goal was to extend the literature by investigating two moderators, calling and competitive climate, of the link between abusive supervision, organizational cynicism, and turnover intention.

Theoretical Implications

First, we examined the mediating role of organizational cynicism on the relationship between abusive supervision and turnover intention, and found that organizational cynicism fully mediates the relationship between abusive supervision and turnover intention. Our findings demonstrate that supervisors may serve as proxies for the organization, and therefore their abusive behaviors might trigger a negative affective attitude about the organization. We confirmed that abusive supervision can be one of the factors that create strong negative attitudes toward supervisors and jobs (Tepper, 2000).

Second, this is the first study to examine the effects of calling under abusive leadership. When the organization is unable to provide a fertile environment to satisfy one's calling at work, it would trigger high level of organizational cynicism, in turn, individuals with high calling show higher turnover rates. In line with Bunderson and Thompson's (2009) argument that the experience of calling is related to one's higher sense of moral duty, higher moral standards for work, and willingness to make personal sacrifices, individuals with high calling are less likely to accept maltreatment by management. They sometimes have extremely high expectations for their organization, and assume that the organization has a moral duty to enable employees to live their calling. If these individuals believe that they have failed to achieve this goal, they might be motivated to leave their jobs. This shows that abusive leadership has greater detrimental impact on individuals with high level of calling.

Lastly, on an organizational level, we found 
significant interactive effects of a competitive climate on the relationship between abusive supervision and organizational cynicism. A competitive dimate weakens the negative effects of abusive supervision, because employees may interpret their supervisors' abusive behaviors as less threatening than employees in a less competitive condition. Employees in a more competitive climate might be less likely to interpret supervisory behaviors as arising from destructive motives to harm performance. Adverse working conditions, such as a competitive climate, may be perceived as justifying abusive supervision.

\section{Practical Implications}

Our findings suggest several implications for management. First, organizations should recognize that abusive supervision can be a major cause of turnover intention among employees, and therefore clear rules regarding-and punishments for engaging in-abusive supervision are essential. Crucially, employees must be given systematic organizational support, including policies that prohibit abusive supervision. In addition to recognizing and eliminating abusive supervision, organizations should identify employees with high organizational cynicism and conduct interventions, with the goal of reducing employees' negative experiences in the organization.

Secondly, organizations should make an effort to eliminate abusive supervision so that employees with high calling could make a greater contribution to their organization. Employees with high calling would show higher turnover intention when they do not believe that the organization is aligned with their values (Berg et al., 2010). On the contrary, they would show greater occupational commitment and satisfaction with their work when they think the organization is congruent with their values (Duffy, Bott, Allan, Torrey \& Dik, 2012). Thus, it is important to develop leadership training programs that emphasize the importance of positive supervisory behavior in order to fully motivate the employees with high calling.

Finally, we demonstrate that the adverse impacts of abusive supervision are mitigated in a high competitive climate. In a high competitive climate, abusive supervision may be less likely to influence employee's cynicism and turnover intention than in a low competitive dimate. Nevertheless, prolonged abusive supervision can significantly harm organizational effectiveness by increasing employee's deviant behavior and lowering affective commitment and job satiffaction among employees in the long term (Han \& Park, 2009; Park, Jung, \& Park, 2015; Tepper, Henle, Lamber, Giacalone, \& Duffy, 2008). Therefore, organizations may need to institute policies that discourage abusive supervision and support an abusefree work environment. 
of abusive supervision and turnover intention.

This study is not without limitations. First, by using cross-sectional data we could not etablish causation, and can only imply correlations between variables. As a correlational study, it also suffers from common method biases (Podsakoff, Mack enzie, Lee, \& Podsakoff, 2003). In the correlational study, the correlations between variables are more likely to be inflated due to the common method bias; therefore, it would be beneficial to conduct a longitudinal study of abusive supervision. Second, we used a simultaneous hierarchical regression model, which might yield less accurate estimates than a multilevel model ( $\mathrm{Ng}$, Chen, \& Aryee, 2012; Tepper, 2007). Thus, other organization-level variables should be considered-such as autonomic, normative, and authoritarian organizational climates-using multilevel models. Lastly, we sampled participants who were employed in the U.S. Previous studies that utilized non-US samples have shown the negative effects of abusive supervision on employee's attitudes and behaviors (Aryee et al., 2008; Lee $\&$ Cho, 2010; Rafferty \& Restubog, 2011; Xu, Huang, Lam, \& Miao, 2012), and this findings are consistent with studies using US samples. However, given that there is a cultural difference in reaction to abusive supervision (Kernan, Watson, Chen, \& Kim, 2011; Lian, Ferris, \& Brown, 2012), future studies should be conducted in non-US cultures to investigate cultural influences in the relation

\section{Conclusion}

This study examines a moderated mediation model of the relationship between abusive supervision and turnover intention. It addresses the crucial role of organizational cynicism in influencing turnover intention. It also provides a framework for the process and mechanisms that underlie abusive supervision, and demonstrates that this relationship could be attenuated or strengthened by individual and organizational factors. Taken together, the study offers valuable insights for future research on the effects of abusive supervision.

\section{References}

한주원, 박경규 (2009). 상사의 비인격적 감독 이 부하의 직장 내 일탈행동에 미치는 영 향. 한국심리학회지: 산업 및 조직, 22, 233-259.

박현선, 정현선, 박동건 (2015). 상사의 비인격

적 감독과 과업수행 수준의 상호작용이 종업원의 조직 냉소주의에 미치는 영향. 한국심리학회지: 산업 및 조직, $28,225-$ 248.

Andersson, L. M. (1996). Employee cynicism: An examination using a contract violation framework. Human Reations, 49, 1395-1418. Arnold, T., Flaherty, K. E., Voss, K. E., \& 
Mowen, J. C. (2009). Role stressors and retail performance: The role of perceived competitive climate. Journal of Retailing, 85, 194-205.

Aryee, S., Sun, L. Y., Chen, Z. X. G., \& Debrah, Y. A. (2008). Abusive supervision and contextual performance: The mediating role of emotional exhaustion and the moderating role of work unit structure. Management and Organization Reviev, 4, 393-411.

Ashforth, B. (1994). Petty tyranny in organizations. Human Relations, 47, 755-778.

Atwater, L., Kim, K. Y., Witt, A., Latheef, Z., Callison, K., Elkins, T. J., \& Zheng, D. (2016). Reactions to abusive supervision: Examining the roles of emotions and gender in the USA. The International Journal of H uman Resource M anagement, 27, 1874-1899.

Bakker, A. B., Demerouti, E., \& Verbeke, W. (2004). Using the job demands resources model to predict burnout and performance. H uman Resource M anagement, 43, 83-104.

Barnes, W. F., \& Jones, E. B.(1974). Differences in male and female quitting. Journal of Human Resources, 9, 439-451.

Becker, T. E. (1992). Foci and bases of commitment: Are they distinctions worth making? A cademy of Management Journal, 35, 232-244.

Bedeian, A. G. (2007). Even if the tower is "Ivory," it isn't "White": Understanding the consequences of faculty cynicism. A cademy of
M anagement Learning \& Education, 6, 9-32.

Berg, J. M., Grant, A. M., \& Johnson, V. (2010). When callings are calling: Crafting work and leisure in pursuit of unanswered occupational callings. Organization Science, 21, 973- 994.

Berkelaar, B. L., \& Buzzanell, P. M. (2015). Bait and switch or doubleedged sword? The (sometimes) failed promises of calling. Human Reations, 68, 157-178.

Brown, S. P., Cron, W. L., \& Slocum Jr., J. W. (1998). Effects of trait competitiveness and perceived intraorganizational competition on salesperson goal setting and performance. Journal of Marketing, 62, 88-98.

Bunderson, J. S., \& Thompson, J. A. (2009). The call of the wild: Zookeepers, callings, and the double-edged sword of deeply meaningful work. Administrative Science Quartely, 54, 32-57.

Cammann, C., Fichman, M., Jenkins, D., \& Klesh, J. (1979). The Michigan organizational assesment questionnaire Unpublished manuscript, University of Michigan, Ann Arbor.

Chiaburu, D. S., Peng, A. C., Oh, I. S., Banks, G. C., \& Lomeli, L. C. (2013). Antecedents and consequences of employee organizational cynicism: A metaanalysis. Jaurnal of Vocational Behavior, 83, 181-197.

Cotton, J. L., \& Tuttle, J. M. (1986). Employee turnover: A meta-analysis and review with implications for research. A cademy of 
M anagement Reviev, 11, 55-70.

Creed, P. A., Rogers, M. E., Praskova, A., \& Searle, J. (2014). Carer calling as a personal resource moderator between environmental demands and burnout in Australian junior doctors, Jaurnal of Carer D evelopment, 41, 547-561.

Cropanzano, R., James, K., \& Konovsky, M. A. (1993). Dispositional affectivity as a predictor of work attitudes and job performance. Jaurnal of Organizational Behavior, 14, 595-606.

Dean, J. W., Brandes, P., \& Dharwadkar, R. (1998). Organizational cynicism. A cademy of Management Review, 23, 341-352.

Duffy, M. K., Ganster, D. C., \& Pagon, M. (2002). Social undermining in the workplace. A cademy of Managenent Jaurnal, 45, 331-351.

Duffy, R. D., Bott, E. M., Allan, B. A., Torrey, C. L., \& Dik, B. J. (2012). Perceiving a calling, living a calling, and job satisfation: testing a moderated, multiple mediator. Journal of Counsding Psychology, 59, 50-59.

Duffy, R. D., Douglass, R. P., \& Autin, K. L. (2015). The dark side of callings, In D. B. Yaden, T. D. McCall, \& J. H. Ellens (Eds.) Being Called: Secular, Sacred, and Scientific Perspectives (pp. 13-25). Santa Barbara, CA: Praeger.

Eisenberger, R., Stinglhamber, F., Vandenberghe, C., Sucharski, I. L., \& Rhoades, L. (2002). Perceived supervisor support: Contributions to perceived organizational support and employee retention. Jarnal of Applied Psychology, 87, 565-573.

Gazica, M. W., \& Spector, P. E. (2015). A comparison of individuals with unanswered callings to those with no calling at all. Journal of Vocational Behavior, 91, 1-10.

Glasø, L., Vie, T. L., Homdal, G. R., \& Einarsen, S. (2011). The application of affective events theory to workplace bullying. European Psychologist, 16, 198-208.

Haggard, D. L., Robert, C., \& Rose, A. J. (2011). Co-rumination in the workplace: Adjustment tradeoffs for men and women who engage in excessive discussions of workplace problems. Journal of Business and Psychology, 26, 27-40.

Hagmaier, T., \& Abele, A. E. (2012). The multidimensionality of calling: Conceptualization, measurement and a bicultural perspective. Journal of Vocational Behavior, 81, 39-51.

Hall, D. T., \& Chandler, D. E. (2005). Psychological success: When the career is a calling. Jarnal of Organizational Behavior, 26, 155-176.

Harris, K. J., Kacmar, K. M., \& Zivnuska, S. (2007). An investigation of abusive supervision as a predictor of performance and the meaning of work as a moderator of the relationship. Leadeship Quartely, 18, 252-263.

Harvey, P., Stoner, J., Hochwarter, W., \& 
Kacmar, C. (2007). Coping with abusive supervision: The neutralizing effects of ingratiation and positive affect on negative employee outcomes. Leadership Quarterly, 18, 264-280.

Hershcovis, M. S., \& Barling, J. (2010). Towards a multi foci approach to workplace aggression: A meta analytic review of outcomes from different perpetrators, Journal of Organizational Behavior, 31, 24-44.

Hinkin, T. R., \& Tracey, J. B. (2000). The cost of turnover: Putting a price on the learning curve. The Cornel Hote and Restaurant Adminisration Quartely, 41, 14-21.

Hom, P. W., Griffeth, R. W., \& Sellaro, C. L. (1984). The validity of Mobley's (1977) model of employee turnover. Organizational Behavior and Human Peformance, 34, 141174.

Jones, J. L., Davis, W. D., \& Thomas, C. H. (2017). Is competition engaging? Examining the interactive effects of goal orientation and competitive work environment on engagement. Human Resource M anagement, 56, 389-405.

Jun, T. H., \& Jeung, W . (2015). The effects of abusive supervision on organizational commitment: Mediating effects of psychological empowerment and organizational identification. Jarnal of Human Resarce M anagement Reserch, 22, 25-47. Kernan, M. C., Watson, S., Chen, F. F., \& Kim, T. G. (2011). How cultural values affect the impact of abusive supervision on worker attitudes. Cross Cultural Management, 18, $464-484$.

Kuo, C. C., Chang, K., Quinton, S., Lu, C. Y., \& Le, I. (2015). Gossip in the workplace and the implications for $H R$ management: A study of gossip and its relationship to employee cynicism. The International Journal of Human Resource Managenent, 26, 2288-2307.

Lee, K. G., \& Cho, Y. H. (2010). The role of trust in supervisor as mediator between abusive supervision and organizational citizenship behaviors. Jaurnal of Human Resource M anagement Research, 17, 173-191.

LePine, J. A., Podsakoff, N. P., \& LePine, M. A. (2005). A meta-analytic test of the challenge stressor-hindrance stressor framework: An explanation for inconsistent relationships among stressors and performance. A cademy of Management Jaurnal, 48, 764-775.

Levinson, H. (1965). Reciprocation: The relationship between man and organization. Administrative Súence Quarterly, 9, 370-390.

Lian, H., Ferris, D. L., \& Brown, D. J. (2012). Does power distance exacerbate or mitigate the effects of abusive supervision? It depends on the outcome. Journal of Applied Psychology, 97, 107-123.

Liu, D., Liao, H., \& Loi, R. (2012). The dark side of leadership: A threelevel investigation of the cascading effect of abusive supervision 
on employee creativity. A cademy of M anagement Journal, 55, 1187-1212.

Liu, X. Y., \& Wang, J. (2013). Abusive supervision and organizational citizenship behaviour: Is supervisor - subordinate guanxi a mediator? The International Journal of H uman Resource M anagement, 24, 1471-1489.

Martinko, M. J., Harvey, P., Brees, J. R., \& Mackey, J. (2013). A review of abusive supervision research. Journal of Organizational Behavior, 34, S120-S137.

Mawritz, M. B., Mayer, D. M., Hoobler, J. M., Wayne, S. J., \& Marinova, S. V. (2012). A trickle down model of abusive supervision. Personne Psychology, 65, 325-357.

Mitchell, T. R., Holtom, B. C., \& Lee, T. W. (2001). How to keep your best employees: Developing an effective retention policy. The Academy of Management Exeative, 15, 96-108.

Muller, D., Judd, C. M., \& Yzerbyt, V. Y. (2005). When moderation is mediated and mediation is moderated. Jaurnal of Pessonality and Social Psychology, 89, 852-863.

Namie, G., \& Namie, R. (2000). W orkplace bullying: The silent epidemic. Employee Rights Quarterly, 1, 1-12.

N g, S. B. C., Chen, Z. X., \& Aryee, S. (2012). A busive supervision in Chinese work settings. In X. Huang, \& M. H. Bond, M.H. (Eds.) Handbook of Chinese Organizational Behavior: Integrating Theory, Research and Practice (pp. 164-183), Cheltenham, UK:
Edward Elgar Publishing.

Park, H. T., Son, S. Y., \& Yun, S. H. (2014).

The types of abusive supervision and task performance. Jaurnal of Human Resource Management Research, 21, 21-46.

Podsakoff, P. M., Mack enzie, S. B., Lee, J. Y., \& Podsakoff, N. P. (2003). Common method biases in behavioral research: a critical review of the literature and recommended remedies. Jaurnal of A pplied Psychology, 88, 879-903.

Praskova, A., Creed, P. A., \& Hood, M. (2015). Self-regulatory processes mediating between calling and perceived employability and life satisfaction in emerging adults. Journal of Carer Development, 42, 86-101.

Preacher, K. J., Rucker, D. D., \& Hayes, A. F. (2007). Addressing moderated mediation hypotheses: Theory, methods, and prescriptions. Multivariate Behavioral Research, 42, 185-227.

Rafferty, A. E., \& Restubog, S. L. D. (2011). The influence of abusive supervisors on followers' organizational citizenship behaviours: The hidden costs of abusive supervision. British Jaurnal of Management, 22, 270-285.

Richman, J. A., Flaherty, J. A., Rospenda, K. M., \& Christensen, M. L. (1992). Mental health consequences and correlates of reported medical student abuse. Jama, 267, 692-694.

Spreitzer, G. M. (1995). Psychological 
empowerment in the workplace: Dimensions, measurement, and validation. A cademy of M anagement Journal, 38, 1442-1465.

Tepper, B. J. (2000). Consequences of abusive supervision. A cademy of Management Jaurnal, 43, 178-190.

Tepper, B. J. (2007). Abusive supervision in work organizations: Review, synthesis, and research agenda. Journal of Management, 33, 261-289.

Tepper, B. J., Henle, C. A., Lambert, L. S., Giacalone, R. A., \& Duffy, M. K. (2008). Abusive supervision and subordinates' organization deviance. Jaurnal of Applied Psychology, 93, 721-732.
Xu, E., Huang, X., Lam, C. K., \& Miao, Q. (2012). Abusive supervision and work behaviors: The mediating role of LMX. Journal of Organizational Behavior, 33, 531-543.

Zhang, Y., \& Bednall, T. C. (2016). Antecedents of abusive supervision: A metaranalytic review. Journal of Business Ethics, 139, 455-471.

1차 원고접수 : 2017. 06. 26

2차 원고접수 : 2017. 08. 22 최종게재결정 : 2017. 08. 25 
한국심리학회지: 산업 및 조직

Korean Journal of Industrial and Organizational Psychology

2017. Vol. 30, No. 2, 443-464

\title{
비인격적 감독의 차별적 영향: \\ 소명의식과 경쟁적 문화의 조절된 매개효과 모델 검증
}

\author{
곽 연 선 \\ 정 예 슬 \\ 손 영 우 \\ 연세대학교 심리학과
}

\begin{abstract}
본 연구는 비인격적 감독과 이직의도를 매개하는 조직 냉소주의의 간접효과에 미치는 소명 의식과 경쟁적 조직문화의 조절효과를 검증하였다. 본 연구는 개인의 소명의식이 높을수록 조직 냉소주의의 간접효과가 강화되고, 경쟁적 조직문화가 높을수록 조직 냉소주의의 간접 효과가 약화될 것이라고 가설을 설정하였다. 본 연구는 가설을 검증하기 위하여 미국 직장 인 236명을 대상으로 설문조사를 실시하여 자료를 수집하였다. 연구결과, 높은 수준의 비인 격적 감독 상황에서, 개인은 조직에 대한 냉소적 태도를 가지게 되며, 높은 이직의도를 초래 한다는 것이 밝혀졌다. 조절된 매개효과를 검증한 결과, 경쟁적 조직문화가 높은 조직일수 록, 조직 냉소주의가 비인격적 감독과 이직의도 사이의 간접효과를 약화시켰다. 반대로, 경 쟁적 조직문화가 낮은 조직일수록, 조직 냉소주의가 비인격적 감독과 이직의도 사이의 간접 효과를 강화시켰다. 또한, 개인의 소명의식이 높을수록, 조직 냉소주의가 비인격적 감독과 이직의도 사이의 간접효과를 강화하는 양상을 보여주었다. 반면에 개인의 소명의식이 낮을 수록, 조직 냉소주의가 비인격적 감독과 이직의도 사이의 간접효과를 약화시켰다. 따라서 본 연구의 가설과 일치하는 결과를 얻을 수 있었다. 본 연구는 비인격적 감독의 효과는 개인의 소명의식 혹은 조직의 문화에 따라 조절될 수 있다는 것을 밝혔다. 본 연구의 메커니즘과 의의, 추후 연구 방향에 대해도 논의하였다.
\end{abstract}

주요어 : 비인격적 감독, 소명의식, 경쟁적 조직문화, 조직 냉소주의, 이직의도 